\title{
Discussion on Experimental Teaching Mode of Costume Design Specialty Based on Innovation Ability Cultivation
}

\author{
Xiaoyan Yang \\ College of Art and Design \\ Huanghe Science and Technology College \\ Zhengzhou, China 450000
}

\begin{abstract}
Experimental teaching plays an important role in the teaching system of costume design specialty, and the key link for cultivating students' innovation ability. However, as an application-oriented discipline with strong characteristics of comprehensiveness and diversification, the practical teaching of costume design specialty pays attention to applicability and practicality of knowledge. But with the influence of various factors, some college students who are specialized in costume design still have deficiency in terms of operation ability and adaptability. Taking this as the background, this paper has analyzed the contents and characteristics of experimental teaching for costume design specialty in the new era, discussed the main problems existing in experimental teaching from the perspective of innovation ability, offered the approaches for optimizing teaching mode, and finally, verified the effects of experimental teaching.
\end{abstract}

Keywords—costume design specialty; experimental teaching; innovation ability; teaching mode

\section{INTRODUCTION}

As a discipline with strong comprehensiveness and application, costume design has combined the theoretical knowledge of such disciplines as aesthetics, ergonomics, chemical dyeing and textiles to the largest extent, and integrate the technologies and skills related to it. In order to enable the students to understand and grasp the theoretical knowledge and practical skills of costume design to the largest extent, more efforts shall be make in terms of experimental teaching in addition to keeping up with the latest cutting-edge theory and capturing the latest fashion elements. This is because that as for costume design specialty, practice is the foundation for professional learning and development. In order to cultivate the high-quality costume designers with strong innovation awareness and practical ability, it is necessary to think in a comprehensive and in-depth way in terms of experimental teaching. What's more, the society will raise higher requirements for costume design posts at present and in the future. Only by possessing related quality and ability, can the graduates be able to adapt to the development of the times, and put what they have learned into application. It can be seen that, experimental teaching plays an important role in teaching system of costume design specialty.

\section{CONTENTS AND FEATURES OF EXPERIMENTAL TEACHING OF COSTUME DESIGN SPECIALTY IN NEW ERA}

As a comprehensive discipline integrating technology and art, costume design has higher requirements for practicality and applicability. In the process of talent cultivation, theoretical teaching and experimental teaching need to be integrated together fully in order to enable students to have solid theoretical foundation, high artistic quality and practical ability, and become the costume professionals with certain innovation spirit. In order to strengthen students' comprehensive ability through experimental teaching, the accurate understanding of experimental teaching's contents and features needs to be formed.

\section{A. Based Process Experiment and Its Characteristics}

As for costume design, basic process design is the direct guarantee of clothing quality, playing a fundamental role in the manufacturing process of ready-made clothing. Therefore, in basic process experiment, teachers shall impart the most fundamental process knowledge and operational skills to the students, to enable them to judge and research the common failures, and to carry out maintenance for the equipment and so on. In addition, as the prerequisite of costume process experiment, basic process experiment shall train students' operation ability with emphasis, enabling them to be familiar with the operation process and operating essentials, develop the occupational habit of standard operation and guaranteeing quality in the continuous experimental teaching, and to put what they have learned into application as well as to combine leaning and using through learning basic theory in-depth. For example, prior to ready-made clothe experiment, students shall be asked to be familiar with the spare parts and use them, take exercises repeatedly and operate flexibly, thus to strengthen the targeted experiment.

\section{B. Comprehensive Ready-Made Cloth and Its Features}

In the process of comprehensive ready-made experiment, students' operation ability shall be cultivated with emphasis, especially shall enable them to grasp the excellent costume process technology and skills. In the actual operation, samples shall be showed to the students, so that they can carry out 
analysis and comparison using the knowledge they have acquired, and judge and research the process methods. As a result, students are able to broaden their knowledge, and can combine theory and practice, to enhance their practice skills. In addition, in the comprehensive ready-made experiment, the extracurricular costume design concept and thoughts can be applied to the experimental teaching, to enhance students' interest motivation in costume design. Of course, in this process, it is necessary to fully understand that the contents of ready-made process experiment are diversified, with many links, and large amount of knowledge is needed to be used in the curriculum system of costume design. Only in this way, can students' knowledge and skills be well-matched with their jobs.

\section{Graduation Design Experiment and Its Features}

At this stage, teachers are required to play to main role, to complete the experimental tasks together with students through in-depth experimental teaching. For the purpose of achieving effective guidance to graduation design experiment, teachers shall analyze students' practical difficulties and provide assistance to them, encourage them to take the initiative to refer to information and data related to the experiment, in order to obtain more detailed information, thus to provide powerful support for graduation design. For example, encourage students to make repeated operation of white greige cloth, make trial production in terms of various sewing technology during the practice, and sum up the experience, to ensure the finished product to achieve satisfactory condition. In addition, after the production of graduation design products is completed, teachers shall still play the main role in the graduation project defense, and give students an objective and fair result through reasonable evaluation on their design achievements. Of course, it is noted that design experiments are student-centered, giving full play the main role of students. In the course of the experiment, students shall be required to design and operate independently, and to solve the problems incurred with their biggest initiative.

\section{MAIN PROBLEMS EXISTING IN EXPERIMENTAL TEACHING OF COSTUME DESIGN SPECIALTY-ANALYSIS BASED ON INNOVATION ABILITY}

As for teaching of costume design specialty, it is very necessary to enhance students' ability of analyzing and solving problems to the largest extent through cultivation of students' innovation awareness and innovative spirit by virtue of experimental teaching. However, we need to be aware that problems such as lack of innovation in experimental teaching contents, the conflict between ability cultivation and the subject itself is obvious, teaching methods and means are separated from innovation ability exist in the process of experimental teaching, which have influenced the cultivation of students' innovation ability directly.

\section{A. Lack of Innovation in Experimental Teaching Content}

The experimental teaching of costume design specialty is a complex and open systematic engineering, and any conservative ideology and thinking habit will have a negative impact on the experimental results. The survey shows that, some of the costume design specialties appear to be very conservative with limited openness in terms of experimental teaching content design, experimental curriculum system is relatively closed, and the experimental teaching mode and experimental requirements are relatively obsolete [7]. The reason for this situation is that the experimental teaching resources of some specialties are very limited; teachers and the leaders who are in charge of teaching cannot take the society's diversified demand for talents into consideration ideally, haven't paid necessary attention to the students' individualized requirements, haven't offered necessary guidance in terms of practical operation contents and operation regulations, resulting in most students' weak operation ability, let alone the cultivation of their innovation ability.

\section{B. Apparent Conflict between Ability Cultivation and the Discipline Itself}

For quite a long time, the teaching of costume design specialty pays great attention to classroom teaching, neglecting the cultivation of students' operation ability, regarding experiment as the appendix of theory, and even put classroom teaching in opposition to experimental teaching. As a result, the traditional teaching system of the discipline is conflict with the requirements of experimental teaching in the new era, the knowledge organization and structural arrangement of experimental curriculum of costume design cannot be scientific, objective and reasonable; at the same time, more importantly, it has resulted in the absence of cultivation of students' ability, making education and teaching disconnected with costume industry. Under such circumstances, colleges only grant students small amount of skills, which appear to be insufficient in practical work in the society. Furthermore, in some colleges, the connection between costume design experimental curriculum and theoretical curriculum hasn't reached the designated position, and students are lack of clear learning objectives, which is not conductive to the cultivation of students' innovation ability.

\section{Separation of Teaching Methods and Means from Innovation Ability Cultivation}

In costume design specialty, although some schools convey the application skills by virtue of experimental teaching, the associated secondary courses occupy quite a large proportion, which has squeezed the experimental curriculum hours to a certain extent, and students will have difficulty in completing the costume design experiment and production due to insufficient experimental space. Generally, in the course of experiment, students watch teachers' demonstration. After teachers have demonstrated the sewing process, they ask students to imitate within a specified period of time, and complete the specific action in accordance with the requirements of the experiment, which will be deemed to have achieved experimental effects as long as they completed the experimental contents. In fact, such experimental teaching mode is easy to make teachers and students generate the inertia of thinking - do as the teachers' requirements and expectation, as long as they have achieved teachers' requirements about the task, they are deeded to be qualified. But in fact, such experiment process will not have positive influence on the 
settlement of practical problems; on the contrary, it will curb the students' creative thinking and innovative behavior.

\section{OPTIMIZATION OF EXPERIMENTAL TEACHING MODE OF COSTUME DESIGN SPECIALTY BASED ON INNOVATION ABILITY CULTIVATION}

As a specialty integrating art and technology, costume design has quite high comprehensive requirements for humanities and natural sciences, and will raise higher and new requirements for the combination of theoretical knowledge and industry practice. Therefore, when conducting experimental teaching, the discipline's characteristics of visibility, practice, comprehensiveness and exploration as well as enlightenment are required to be reflected, to make the experiment process meet the cognitive rules of costume design specialty better. This paper believes that efforts shall be make simultaneously in terms of experiment level, experiment content and experiment process based on the above analysis, in order to optimize the experimental teaching effect.

\section{A. Make Experiment Process Project-Oriented}

For the integrity and systematicness of costume design experiment, it is necessary to adopt project-oriented management for the experiment. First of all, divide the students into groups, and establish clothing company in accordance with the different groups, and set up and adjust organizational structure in accordance with the requirements of business management, so that every student will be able to enter the appropriate department in the form of simulation, and undertake relevant responsibilities; secondly, give play to the role of costume design department, so that it can put forward product program after market research, and formulate production plan according to enterprise strategy requirements; here, the purchasing department is required to conduct market purchasing, and production department shall join in, so as to produce industrial pattern, and play an active role in material layout, production and the like; finally, cost accounting shall be made, and compare it with the actual sales of clothing. As a result, a real costume design environment is created for the students, and students' team work ability as well as their innovation \& enterprise capability can be cultivated.

\section{B. Make the Experimental Projects Layered}

In the process of costume design experimental teaching, the experimental projects shall be made into layers, so as to provide targeted cultivation of students' application skills. Among them, the basic experiment is designed to deepen students' understanding and mastery of the basic theory, cultivating students' basic experimental skills. In this process, students are required to complete the task in accordance with the experimental procedures, and make recording and processing of experimental data, and then obtain the experimental results through comprehensive analysis; comprehensive design experiment aims to cultivate students' ability of conducting experiments independently, thus to strengthen students' innovation ability by analyzing and solving the problems. In general cases, teachers should give the experimental title in advance, and raise requirements about experimental process. At the same time, they shall supervise, inspect and guide the experimental process; and as for research and innovative experiments, students' innovative and entrepreneurial ability shall be cultivated with emphasis, so as to help students adapt to the requirements of economic and social development upon they have a job.

\section{Make Experimental Content Modularized}

When optimizing the experimental content of costume design specialty, it shall be divided into such modules as cognitive experiment, engineering technical experiment, product design experiment as well as innovation and entrepreneurship experiment, so as to cultivate students systematically. Among them, the cognitive practice module involves basic technology cognition and artistic basic cognition, cultivating students' basic skills by adding these elements; engineering technical module involves clothing constitute technology and ready-made clothing processing technology, to ensure that students can master the professional knowledge and expertise of costume design; product design module involves the design and production of ready-made products, and require to form high ability about product design and production; innovation and entrepreneurship module requires the experiments to be individualized and open, enabling students to master the knowledge and skills about brand planning and marketing simulation through innovative experiments, which is conducive to the cultivation of students' innovation ability.

\section{ACTUAL EFFECT OF EXPERIMENTAL TEACHING OF COSTUME DESIGN SPECIALTY}

The ultimate goal of experimental teaching of costume design specialty is to cultivate the professionals of costume with solid theoretical foundation, high artistic quality, strong practical ability and rich innovative spirit. After optimization of existing experimental teaching, the teaching effect of this specialty of our school is enhanced significantly and talent cultivation quality is improved continuously, which are mainly reflected in the following aspects:

\section{A. Students' Comprehensive Innovation Ability Is Strengthened}

Experience shows that the actual effect of costume design shall be achieved by virtue of demonstration, and integration of human and clothing can reflect the beauty of state. In the costume design specialty of our school, the experimental teaching requires students to participate in the whole process of it, so as to ensure the style chart and design sketch can satisfy themselves and other classmates; at the same time, regulations on the selection of fabric and the expression of design intent have been made, to prevent the separation of ready-made products from the original design concept. Not only students' operation ability is enhanced, but their comprehensive design ability and innovation ability are also cultivated. 


\section{B. Students' Learning Ability and Innovation Ability Are Enhanced}

Huanghe S\&T College has opened the experimental teaching project of "cutting-edge design and production of women's trousers", adding the elements such as season and fashion trend into the experimental process. While guiding students in the experiment, teachers shall encourage students to complete costume design independently and make sure they themselves are willing to wear what they are designing. Students' enthusiasm has been greatly improved, and the number of students who apply for this experimental project has exceeded the experiment capacity. This shows that students' initiative and subjectivity can be enhanced effectively by motivation and changing the experimental content, which is of great help to promote their positive thinking, completing the transformation from "I am forced to do experiments" to "I want to do experiments".

\section{Students' Innovative Design Confidence Is Enhanced}

The training of open mode is adopted for realization of costume design. Students are able to make reasonable adjustment to the model according to their own design intent, and to make comprehensive analysis and optimization for the cut-parts and sample sheet. During this period of time, professional teachers are required to participate in to guide and help students. As a result, the ready-made products will satisfy the students after their repeated modification. More importantly, students' costume design creative performance has been expressed and demonstrated fully. Thus their passion in innovation rises continuously with more apparent entrepreneurial intention.

\section{CONCLUSION}

The experimental teaching of costume design is very complicated, having high requirements for teachers and students. During the experiment, the application and practicality of the knowledge shall be stressed with emphasis, and at the same time, further attention shall be paid to knowledge accumulation. Only in this way, can students' theoretical elementary knowledge be intensified constantly through experimental teaching, and to further cultivate their operation ability, practice ability and innovation ability. At present, the whole country has set expectation on innovation and entrepreneurship. The college costume design specialty shall seize this opportunity and support students to participate in experimental teaching and scientific research, to promote experimental teaching reform constantly through strengthening experimental teaching link and optimizing experimental teaching content, thus to enhance experimental teaching quality to the largest extent, and make more contribution to the cultivation of innovative and entrepreneurial talents.

\section{REFERENCES}

[1] Wang Haiyang. Conception of Experimental Teaching for College Costume Design Specialty Courses [J].Journal of Ningbo University, 2014 (5): 67-69.
[2] Zhang Min. Practical Design of Innovative Talent Cultivation Environment [J]. Research on Economics and Management, 2013 (7): 67-70. 